\title{
Ants (Hymenoptera: Formicidae) as Carriers of Fungi in Hospital Environments: An Emphasis on the Genera Tapinoma and Pheidole
}

Author(s): L.D.M. Pantoja, R. E. Moreira Filho, E.H.S. Brito, T. B. Aragão, R.S.N. Brilhante, R. A. Cordeiro, M.F.G. Rocha, A. J. Monteiro, Y. P. Quinet, and J.J.C. Sidrim

Source: Journal of Medical Entomology, 46(4):895-899. 2009.

Published By: Entomological Society of America

DOI: http://dx.doi.org/10.1603/033.046.0423

URL: http://www.bioone.org/doi/full/10.1603/033.046.0423

BioOne (www.bioone.org) is a nonprofit, online aggregation of core research in the biological, ecological, and environmental sciences. BioOne provides a sustainable online platform for over 170 journals and books published by nonprofit societies, associations, museums, institutions, and presses.

Your use of this PDF, the BioOne Web site, and all posted and associated content indicates your acceptance of BioOne's Terms of Use, available at www.bioone.org/page/terms_of_use.

Usage of BioOne content is strictly limited to personal, educational, and non-commercial use. Commercial inquiries or rights and permissions requests should be directed to the individual publisher as copyright holder. 


\title{
Ants (Hymenoptera: Formicidae) as Carriers of Fungi in Hospital Environments: An Emphasis on the Genera Tapinoma and Pheidole
}

\author{
L.D.M. PANTOJA ${ }^{1,2,3}$ R. E. MOREIRA FILHO, ${ }^{1,2}$ E.H.S. BRITO ${ }^{1,4}$ T. B. ARAGÃO,${ }^{5,6}$ \\ R.S.N. BRILHANTE,${ }^{1,2,7}$ R. A. CORDEIRO, ${ }^{1,2,5}$ M.F.G. ROCHA, ${ }^{1,2,4}$ A. J. MONTEIRO, ${ }^{8}$ \\ Y. P. QUINET, ${ }^{5,6}$ AND J.J.C. SIDRIM ${ }^{1,2}$
}

J. Med. Entomol. 46(4): 895-899 (2009)

\begin{abstract}
The aim of this study was to evaluate the presence of filamentous fungi and yeasts on the external surface of ants at hospitals. From March 2007 to February 2008, 2,899 ants were evaluated in two public hospitals in the city of Fortaleza, Ceará, in northeastern Brazil. The ants were attracted by nontoxic baits, distributed within critical and semicritical hospital areas. The fungi were identified through macroand micromorphological analysis, biochemical profile, and growth in chromogenic medium. From this study, 5 genera and 13 species of ants were identified, from critical (8\% of the collected ants) and semicritical (92\%) areas, during the daytime (48\%) and nighttime (52\%) periods. In the mycological analysis, $75 \%$ of the ants were fungi carriers, with the species Tapinoma melanocephalum and species from the genus Pheidole having the most potential as carriers of airborne fungi (75 and 18\%, respectively) and yeasts ( 6 and $1 \%$, respectively). In summary, ants act as carriers of airborne fungi and yeasts, including some pathogenic species.
\end{abstract}

KEY WORDS ants, Tapinoma, Pheidole, fungi, hospital environment

Arthropods correspond to $75 \%$ of the earth's animals, and $89 \%$ of them are insects (Brusca and Brusca 2003). They are the group with the greatest number of species distributed in temperate and particularly tropical countries (Chacón de Ulloa 2003).

Because of the close association of insects with humans, their role as potential mechanical carriers of pathogenic microorganisms has been studied. Some authors have reported adult insects and nymphs carrying viruses, bacteria, fungi, and protozoa, as well as serving as intermediate hosts of helminthes (Robinson 1996, Mariconi 1999), thus posing a potential danger to public health.

This risk can be associated with different insects, with emphasis on the following orders: Diptera (flies and mosquitoes) (Fotedar 2001, Graczyk et al. 2003), Blattodea (cockroaches) (Imamura et al. 2003, Lemos et al. 2006), and Hymenoptera (bees, wasps, and ants). Because of their dominant behavior, ants can cause

\footnotetext{
${ }^{1}$ Specialized Medical Mycology Center, Federal University of Ceará, Ceará, Brazil.

2 Postgraduate Program in Medical Microbiology, Federal University of Ceará, Ceará, Brazil.

${ }^{3}$ Corresponding author: Rua Otávio Costa 28, Edson Queiroz, CEP 60812-410, Fortaleza CE, Brazil (e-mail: lydiapantoja@bol.com.br).

${ }^{4}$ Postgraduate Program in Veterinary Science, State University of Ceará, Ceará, Brazil.

${ }^{5}$ Department of Biological Science, State University of Ceará, Ceará, Brazil

${ }^{6}$ Laboratory of Entomology, State University of Ceará, Ceará, Brazil.

${ }^{7}$ Corresponding author, e-mail: brilhante@ufc.br.

${ }^{8}$ Department of Statistics and Applied Mathematics, Federal University of Ceará, Ceará, Brazil.
}

serious problems to humans, and some are considered urban pests. Great efforts have been made to control ants, but most of the results have only temporary effects (Bueno and Campos-Farinha 1999).

Since the first reports of the African species Monomorium pharaonis in European hospitals (Beatson 1972), the possible effects on human health of ants in hospitals roused interest because of the great adaptability and the free contact of these insects with hospital material, wastes, and patients themselves, and their consequent capacity to transmit pathogenic microorganisms. Therefore, ants can act as an important source of hospital bacterial infection (Zarzuela et al. 2002, Chacón de Ulloa 2003).

Ant monitoring in hospital environments is still rare and unevenly distributed (Chacón de Ulloa 2003). Hospitals in tropical countries have classified environments according to the risk of hospital infection into critical and semicritical areas. Critical areas offer potential risk of infection, characterized by closed environments with air conditioning or other climate control, although semicritical areas are occupied by patients who do not need intensive care or isolation and are generally open environments without climate control (Brasil 1985).

Some studies have shown that ants can carry bacteria such as Acinetobacter spp., Corynebacterium spp., Enterobacter spp., Enterococcus spp., Klebsiella spp., Pseudomonas spp., Serratia spp., and Staphylococcus spp. (Lise et al. 2006, Rodovalho et al. 2007). Concerning fungi, there are reports of the presence of 
Table 1. Number of ants captured per species in the various sectors of two hospitals in the city of Fortaleza, Ceará, Brazil, from Mar. 2007 to Feb. 2008

\begin{tabular}{|c|c|c|c|c|c|c|c|c|c|c|}
\hline \multirow{4}{*}{ Ant species } & \multicolumn{10}{|c|}{ Hospital environment } \\
\hline & \multicolumn{5}{|c|}{ Critical areas } & \multicolumn{5}{|c|}{ Semicritical areas } \\
\hline & \multicolumn{2}{|c|}{$\begin{array}{c}\text { Hospital A } \\
\text { IF }(n)\end{array}$} & \multicolumn{3}{|c|}{ Hospital B IF $(n)$} & \multicolumn{3}{|c|}{ Hospital A IF $(n)$} & \multicolumn{2}{|c|}{$\begin{array}{c}\text { Hospital B } \\
\text { IF }(n)\end{array}$} \\
\hline & ICU & $\mathrm{SC}$ & ICU & ICUneoI $^{a}$ & ICUneoII $^{a}$ & PW & HW & TW & SW & GW \\
\hline Tapinoma melanocephalum & 13 & 13 & - & 78 & 91 & 260 & 260 & 247 & 299 & 312 \\
\hline Paratrechina longicornis & - & - & - & 26 & - & 52 & 52 & 78 & 130 & 130 \\
\hline Pheidole impressa & - & - & - & - & - & 65 & 13 & - & - & - \\
\hline Pheidole radoszkowskii & - & - & - & - & - & 26 & - & - & - & - \\
\hline Pheidole sp. diligens group & - & - & - & - & - & - & - & - & - & 78 \\
\hline Pheidole sp. fallax group & - & - & - & - & - & 169 & - & - & - & - \\
\hline Solenopsis globularia & - & - & - & - & - & 52 & - & 13 & 26 & 39 \\
\hline Solenopsis saevissima & - & - & - & - & - & 13 & 13 & - & - & - \\
\hline Solenopsis sp. & - & - & - & - & - & - & - & - & - & 13 \\
\hline Camponotus arboreus & - & - & - & - & - & - & 104 & - & - & - \\
\hline Camponotus melanoticus & - & - & - & - & - & - & 13 & 13 & - & - \\
\hline Camponotus renggeri & - & - & - & - & - & - & - & - & - & 13 \\
\hline Camponotus vittatus & - & - & - & - & - & - & 91 & 104 & - & - \\
\hline Total & 13 & 13 & - & 104 & 91 & 637 & 546 & 455 & 455 & 585 \\
\hline
\end{tabular}

${ }^{a}$ Two neonatal ICUs at the same hospital, but in different buildings.

-, absence; $n$, no. of ants captured; ICU, adult intensive care unit; SC, surgery center; ICUneoI, neonatal intensive care unit I; ICUneoII, neonatal intensive care unit II; PW, pediatrics ward; HW, hematology ward; TW, transplant ward; SW, surgery ward; GW, gynecology ward.

airborne fungi such as Aspergillus spp., Penicillium spp., and Cladosporium spp. (Barros et al. 2006), as well as yeasts, especially from the genus Candida spp. (Barros et al. 2006).

The increase of opportunistic fungal infections has led to a search for the sources of contamination inside hospital environment (Perdelli et al. 2006). However, few studies are available on the real involvement of ants as fungus carriers. The aim of this study was to evaluate the presence of filamentous fungi and yeasts on the external surface of ants at public hospitals in northeastern Brazil.

\section{Materials and Methods}

The study was conducted in two public hospitals (hospital A and hospital B), which act in tertiary care, education, and research and are both located in the city of Fortaleza, Ceará. In each hospital, five sectors were analyzed, grouped according to the risk of hospital infection (Brasil 1985): critical areas (intensive care unit [ICU] and surgical ward) and semicritical areas (infirmaries). This study was submitted to analysis of the research ethics committees of the two institutions and obtained consent in February 2007.

From March 2007 to February 2008, ants were collected on a monthly basis, just after cleaning activities in the daytime and just after the changeover to the nighttime shift. A total of 2,899 ants were analyzed, collected during the day $(1,391)$ and night $(1,508)$.

The ants were attracted by nontoxic and sterilized baits, consisting of honey and commercial cat food (Zarzuela et al. 2002), with the addition of sterile cotton. Fifteen baited traps were set out in each hospital sector. Two samples were collected from each positive bait (with ants): one with 3 ants for entomological identification (total of 669 ants) and another with 10 ants for mycological analysis (total of 2,230 ants) (Moreira et al. 2005).

The ants were mounted with entomological pins and examined under a stereoscopic microscope for identification using identification keys (Bolton 1994).

To isolate the filamentous fungi and yeasts, in each sample with 10 ants, $1.0 \mathrm{ml}$ of saline solution was added to each sample of 10 ants. Aliquots were distributed on the surface of the following culture media: Sabouraud agar medium (Sanofi, Paris, France) supplemented with vancomycin $(0.1 \mathrm{~g} /$ liter $)$ and polymyxin $\mathrm{B}$ (0.0075 g/liter), caffeic acid agar medium, and Niger agar medium. These last two media were used to assist in the presumptive identification of the genus Cryptococcus (Vidotto et al. 2004, Pedroso et al. 2007). The culture media were incubated for $15 \mathrm{~d}$ at $26-28^{\circ} \mathrm{C}$ and examined on a daily basis.

Filamentous fungi were identified by macroscopic and microscopic examination of the characteristics of fungal colonies with the aid of identification keys (Hoog et al. 2000). For identification of yeast, the following tests were conducted: germinative tube, microculture in cornmeal agar with Tween 80 (Difco, Detroit, MI), growth in CHROMagar (Candida, Paris, France), auxonogram, zimogram subcultures, and nitrogen assimilation (Gautret et al. 2000, Hoog et al. 2000).

\section{Results}

Five genera and 13 species of ants were identified. Species from the genera Tapinoma ( $n=1,573$ ants) and Paratrechina $(n=468)$ were the most abundant, followed by Pheidole $(n=351)$, Camponotus ( $n=$ $338)$, and Solenopsis $(n=169)$.

These genera were distributed in critical ( $8 \%$ of collected ants) and semicritical areas (92\%) (Table 1). The species T. melanocephalum and P. longicornis were 
Table 2. Association between no. of fungi isolated and ants genera sampled monthly in hospital $A$ and hospital B from Mar. 2007 to Feb. 2008

\begin{tabular}{|c|c|c|c|c|c|c|c|c|c|c|}
\hline \multirow{3}{*}{ Fungal species } & \multicolumn{10}{|c|}{ Ant genera and hospital } \\
\hline & \multicolumn{2}{|c|}{ Tapinoma } & \multicolumn{2}{|c|}{ Paratrechina } & \multicolumn{2}{|c|}{ Pheidole } & \multicolumn{2}{|c|}{ Solenopsis } & \multicolumn{2}{|c|}{ Camponotus } \\
\hline & A & B & A & $\mathrm{B}$ & A & $\mathrm{B}$ & A & $\mathrm{B}$ & A & B \\
\hline \multicolumn{11}{|l|}{ Airborne fungi } \\
\hline Absidia sp. & 2 & - & - & - & 1 & - & - & - & - & - \\
\hline Acremonium sp. & 1 & 1 & - & - & 2 & - & 1 & - & - & - \\
\hline Acremonium hyalinulum & 3 & 1 & 1 & - & - & - & - & - & - & - \\
\hline Aspergillus flavus & 22 & 16 & 1 & 4 & 8 & 4 & 2 & 1 & 1 & - \\
\hline Aspergillus niger & - & 7 & - & 1 & - & - & - & - & 1 & - \\
\hline Aspergillus ochraceus & 21 & 26 & 2 & 5 & 5 & 3 & 3 & 1 & - & - \\
\hline Aspergillus oryzae & 3 & 5 & - & 1 & 1 & 1 & 1 & 1 & - & - \\
\hline Aspergillus sydowii & 2 & - & 1 & - & - & - & - & - & - & - \\
\hline Aspergillus versicolor & 2 & - & - & - & - & - & - & - & - & - \\
\hline Chrysosporium inops & 2 & 1 & 1 & 1 & - & - & - & 1 & - & - \\
\hline $\begin{array}{l}\text { Cladosporium } \\
\text { sphaerospermum }\end{array}$ & 8 & 5 & 2 & - & 6 & 1 & - & - & 1 & - \\
\hline Cokeromyces sp. & 4 & - & - & - & - & - & - & - & - & - \\
\hline $\begin{array}{l}\text { Cunninghamella } \\
\text { bertholletiae }\end{array}$ & 8 & 8 & 1 & - & 1 & 1 & 1 & 1 & - & - \\
\hline Cyphellophora sp. & 2 & - & - & - & - & - & - & - & - & - \\
\hline Fusarium sp. & - & - & 1 & - & 1 & - & 1 & - & - & - \\
\hline Fusarium proliferatum & 2 & - & - & - & - & - & - & - & - & - \\
\hline Fusarium solani & - & 1 & - & - & - & - & - & - & - & - \\
\hline Mortierella polycephala & - & - & - & 1 & 2 & - & - & - & - & - \\
\hline Mucor sp. & 3 & 1 & - & - & - & - & - & - & - & - \\
\hline Mycocentrospora acerina & 1 & - & - & - & 1 & - & - & - & - & - \\
\hline Ochroconis gallopava & 2 & - & - & - & - & - & - & - & - & - \\
\hline Paecilomyces marquandii & 1 & 1 & - & - & - & - & - & - & - & - \\
\hline Paecilomyces variotii & 2 & 1 & - & - & 1 & - & - & - & - & - \\
\hline Penicillium sp. & 20 & 25 & 4 & 3 & 7 & - & 1 & 1 & - & - \\
\hline Rhinocladiella aquaspersa & - & 2 & - & - & 1 & - & - & - & - & - \\
\hline Scopulariopsis koningii & 2 & - & - & - & - & - & - & - & - & - \\
\hline Scytalidium sp. & - & - & - & - & 1 & - & - & - & - & - \\
\hline Tritirachium oryzae & 1 & - & - & - & - & - & - & - & - & - \\
\hline \multicolumn{11}{|l|}{ Yeasts } \\
\hline Candida albicans & 2 & 1 & - & - & - & - & - & - & - & - \\
\hline Candida glabrata & 1 & - & - & - & - & - & - & - & - & - \\
\hline Candida guilliermondii & 1 & - & - & - & 1 & - & - & - & - & - \\
\hline Candida parapsilosis & 3 & 4 & - & - & - & 1 & - & - & - & - \\
\hline Rhodotorula sp. & 2 & - & - & - & - & - & - & - & - & - \\
\hline Rhodotorula mucilaginosa & - & - & - & - & 1 & - & - & - & - & - \\
\hline Saccharomyces sp. & - & 3 & - & - & - & - & - & - & - & - \\
\hline
\end{tabular}

- , absence.

the most frequent in semicritical areas (68 and $22 \%$, respectively) and critical areas (10 and $2 \%$, respectively). Concerning collection period, $48 \%$ of the ants were collected during the day and $52 \%$ at night.

The mycological analysis showed that 1,660 (75\%) ants were fungus carriers. T. melanocephalum and species from the genus Pheidole had the highest potential as carriers of airborne fungi ( 75 and $18 \%$, respectively) and yeasts ( 6 and $1 \%$, respectively). Of the fungi identified, airborne fungi (94\%) were the most frequent on the external surface of the ants. Only $6 \%$ of the ants carried yeasts (Table 2).

Regarding the distribution, in each hospital environment, of the fungi isolated from ants, a higher frequency of airborne fungi and yeasts in semicritical areas was observed ( 83 and $6 \%$, respectively) than in critical areas (only $11 \%$ of airborne fungi; Table 3 ).

Finally, analysis of the evolution of the infestation index (relative frequency of positive baits) in both hospitals as a function of monthly rainfall showed no significant statistical relationship $\left(\chi^{2}\right.$ test, $\left.P>0.05\right)$.

\section{Discussion}

In hospitals in the southeastern and southern regions of Brazil, the presence of ants of the genera Tapinoma, Paratrechina, Pheidole, Solenopsis, and Camponotus has been reported (Zarzuela et al. 2002, Lise et al. 2006). These genera are known as typically associated with urban environments (Passera and Aron 2005). The taxonomic structure of fauna shown in these studies is similar to the one found in both hospitals in this research.

Of the 13 species identified, the two most frequent ( $T$. melanocephalum and P. longicornis) are considered the two most often occurring in urban/hospital environments in Brazil and other South American countries and are responsible for the highest number of complaints and concern in these environments (Chacón de Ulloa 2003, Moreira et al. 2005). They possess biological characteristics that favor their establishment and propagation in urban environments, such as highly polygynic colonies, small size of workers and queens, generalist diet, great flexibility concerning nesting places, reproduction by 
Table 3. Distribution of fungi isolated from the external surface of ants collected from several sectors of two hospitals in the city of Fortaleza, Ceará, Brazil, from Mar. 2007 to Feb. 2008

\begin{tabular}{|c|c|c|c|c|c|c|c|c|c|c|}
\hline \multirow{4}{*}{ Fungal species } & \multicolumn{10}{|c|}{ Hospital environmental } \\
\hline & \multicolumn{5}{|c|}{ Critical areas } & \multicolumn{5}{|c|}{ Semicritical areas } \\
\hline & \multicolumn{2}{|c|}{ Hospital A } & \multicolumn{3}{|c|}{ Hospital B } & \multicolumn{3}{|c|}{ Hospital A } & \multicolumn{2}{|c|}{ Hospital B } \\
\hline & ICU & $\mathrm{SC}$ & ICU & ICUneoI $^{a}$ & ICUneoII $^{a}$ & PW & HW & TW & SW & GW \\
\hline \multicolumn{11}{|l|}{ Airborne fungi } \\
\hline Absidia sp. & - & - & - & - & - & 1 & 2 & - & - & - \\
\hline Acremonium sp. & - & - & - & - & 1 & 2 & 1 & 1 & - & - \\
\hline Acremonium hyalinulum & - & - & - & - & - & 1 & 1 & 2 & - & 1 \\
\hline Aspergillus flavus & 1 & - & - & 4 & 1 & 16 & 12 & 4 & 7 & 14 \\
\hline Aspergillus niger & - & - & - & 1 & 1 & - & 1 & - & 3 & 3 \\
\hline Aspergillus ochraceus & 1 & - & - & 5 & 3 & 10 & 8 & 11 & 11 & 17 \\
\hline Aspergillus oryzae & - & - & - & - & 2 & 2 & 2 & 1 & 2 & 4 \\
\hline Aspergillus sydowii & - & - & - & - & - & - & 1 & 2 & - & - \\
\hline Aspergillus versicolor & - & - & - & - & - & - & - & 2 & - & - \\
\hline Chrysosporium inops & - & - & - & - & - & 1 & - & 2 & 2 & 1 \\
\hline $\begin{array}{l}\text { Cladosporium } \\
\text { sphaerospermum }\end{array}$ & - & - & - & 1 & 1 & 11 & 2 & 4 & 1 & 3 \\
\hline Cokeromyces sp. & - & - & - & - & 2 & - & - & 2 & - & - \\
\hline $\begin{array}{l}\text { Cunninghamella } \\
\text { bertholletiae }\end{array}$ & - & - & - & 1 & 1 & 1 & 4 & 5 & 6 & 3 \\
\hline Cyphellophora sp. & - & - & - & - & - & - & - & 2 & - & - \\
\hline Fusarium sp. & - & - & - & - & - & 3 & - & - & - & - \\
\hline Fusarium proliferatum & - & - & - & - & - & - & 1 & 1 & - & - \\
\hline Fusarium solani & - & - & - & - & - & - & - & - & - & 1 \\
\hline Mortierella polycephala & - & - & - & - & - & 2 & - & - & 1 & - \\
\hline Mucor sp. & - & - & - & - & - & 1 & 1 & 1 & 1 & - \\
\hline Mycocentrospora acerina & - & - & - & - & - & 1 & 1 & - & - & - \\
\hline Ochroconis gallopava & - & - & - & - & - & 2 & - & - & - & - \\
\hline Paecilomyces marquandii & - & - & - & - & - & 1 & - & - & 1 & - \\
\hline Paecilomyces variotii & - & - & - & - & - & 1 & - & 2 & 1 & - \\
\hline Penicillium sp. & - & 1 & - & 3 & 5 & 14 & 9 & 8 & 12 & 9 \\
\hline Rhinocladiella aquaspersa & - & - & - & 1 & - & 1 & - & - & 1 & - \\
\hline Scopulariopsis koningii & - & - & - & - & - & - & - & 2 & - & - \\
\hline Scytalidium sp. & - & - & - & - & - & 1 & - & - & - & - \\
\hline Tritirachium oryzae & - & - & - & - & - & - & - & 1 & - & - \\
\hline \multicolumn{11}{|l|}{ Yeast } \\
\hline Candida albicans & - & - & - & - & - & 2 & - & - & 1 & - \\
\hline Candida glabrata & - & - & - & - & - & 1 & - & - & - & - \\
\hline Candida guilliermondii & - & - & - & - & - & 1 & - & 1 & - & - \\
\hline Candida parapsilosis & - & - & - & - & - & 2 & 1 & - & 1 & 4 \\
\hline Rhodotorula sp. & - & - & - & - & - & - & 2 & - & - & - \\
\hline Rhodotorula mucilaginosa & - & - & - & - & - & 1 & - & - & - & - \\
\hline Saccharomyces sp. & - & - & - & - & - & - & - & - & 1 & 2 \\
\hline
\end{tabular}

${ }^{a}$ Two neonatal ICUs at the same hospital, but in different buildings.

-, absence; $n$, no. of ants captured; ICU, adult intensive care unit; SC, surgery center; ICUneoI, neonatal intensive care unit I; ICUneoII, neonatal intensive care unit II; PW, pediatrics ward; HW, hematology ward; TW, transplant ward; SW, surgery ward; GW, gynecology ward.

sociotomy (colony fragmentation), and ability to easily change colonies from one place to another one (Chacón de Ulloa 2003, Passera and Aron 2005).

The semicritical areas in this study were highly prone to ant infestation, a pattern found in other studies (Moreira et al. 2005, Rodovalho et al. 2007). The substantially higher infestation observed in infirmaries could be related to a greater number of passersby, more available food for colonies, less rigorous hygiene, and lack of air conditioner (Bicho et al. 2007). In contrast, the infestation level was relatively low in critical areas, where only two ant species (T. melanocephalum and P. longicornis) were found, unlike the findings of studies conducted in other Brazilian hospitals, where neonatal wards and ICUs presented high levels of infestation (>40\%) (Bueno and CamposFarinha 1999). Air-conditioned environment and restricted access to those areas could explain the observed low infestation level.

Regarding ant distribution by period, the higher number of ants captured at night can be explained by the presence of the genus Camponotus, characterized for its essentially nocturnal habits (Bueno and Campos-Farinha 1999), whereas the other genera found are more adapted to different periods of the day (Chacón de Ulloa 2003).

In this study, T. melanocephalum and the species of the genus Pheidole were carriers of airborne fungi and yeasts, whereas other genera only carried airborne fungi. Studies have shown that hospital infections can be caused by certain groups of fungi isolated from ants. This is the case of yeasts of the Candida genus and several species of airborne fungi, such as Aspergillus, Cladosporium, and Penicillium (Perdelli et al. 2006).

Among opportunistic fungi, the presence of yeasts from the Candida genus on ants is notable because it is the most important yeast genus implicated in human infections and is associated with almost $80 \%$ of the hospital fungal infections, representing the main cause of fungemia (Moretti 2007). Species from this genus can cause several diseases, such as arthritis, osteomyelitis, endocarditis, meningitis, and endophthalmitis 
(Pfaller and Yu 2001). Other yeasts were isolated from the ants, such as Rhodotorula and Saccharomyces. This is an important observation, because these agents in contact with patients can cause infection, depending on some factors, such as the immune status of the patient (Ruiz-Esquide et al. 2002).

Therefore, the data suggest that ants can represent a risk to the patients, although the real involvement of these insects with transmission of illnesses is hard to demonstrate for ants, as well as other insects (Lemos et al. 2006). We should also point out the difficulty of differentiating the effects of fungi on ants and in hospital air, because the great majority of the fungi found in both the critical and semicritical areas were airborne species.

In summary, ants act as carriers of airborne fungi and yeasts and could therefore represent a potential risk to hospital patients. There is a need for better control of these insects in semicritical areas because of the presence of immunocompromised patients. In addition, these semicritical areas are important because they are the entrance to critical areas.

\section{Acknowledgments}

We thank the Myrmecology Laboratory of CEPLAC/ UESC (Cacau Study Center/State University of Santa Cruz, Ilhéus, Bahia) for confirmation of the identifications. This study was supported by a grant from CAPES (Coordination Office for University Improvement). CNPq process: 475724/ 2006-2 and 620161/2006-0.

\section{References Cited}

Barros, R.A.M., A. E. Campos-Farinha, and F. Prezoto. 2006. Ocorrência, comportamento e vetoração de fungos por formigas no Hospital da Universidade Federal de Juiz de Fora, Minas Gerais. Ver. Bras. Zooc. 8: 217.

Beatson, S. H. 1972. Pharaoh's ants as pathogen vectors in hospitals. Lancet 299: 425-427.

Bicho, C. L., M.L.C. Brancão, and S. M. Pires. 2007. Mirmecofauna (Hymenoptera, Formicidae) em hospitais e postos de saúde no município de Bagé, RS. Arq. Inst. Biol. 74: 373-377.

Bolton, B. 1994. Identification guide to the ant genera of the world. Harvard University Press, Cambridge, MA.

Brasil Ministério da Saúde. 1985. Coordenação de Controle de Infecção Hospitalar. Manual de Controle de Infecção Hospitalar. Brasília-Distrito Federal, Brazil.

Brusca, R.C., and G. J. Brusca. 2003. Invertebrates. Sinauer Publishers, Sunderland, MA.

Bueno, O. C., and A.E.C. Campos-Farinha. 1999. As formigas domésticas, pp. 135-180. In F.A.M. Mariconi (ed.), Insetos e outros invasores de residências. FEALQ, Piracicaba, São Paulo Brazil.

Chacón de Ulloa. 2003. Hormigas urbanas, pp. 351-359. In F. Fernández (ed.), Introducción a las Hormigas de la región Neotropical. Instituto de Investigación de Recursos Biológicos Alexander von Humboldt, Bogotá, Colombia.

Fotedar, R. 2001. Vector potential of houseflies (Musca domestica) in the transmission of Vibrio cholerae in India. Acta Trop. 78: 31-34.
Gautret, P., M. H. Rodier, C. Kauffmann-Lacroix, and J. L. Jacquemin. 2000. Case report and review. Onychomycosis due to Candida parapsilosis. Mycoses 43: 433-435.

Graczyk, T. K., B. H. Grimes, R. Knight, A. J. Silva, N. J. Pieniazek, and D. A. Veal. 2003. Detection of Cryptosporidium parvum and Giardia lamblia carried by synanthropic flies by combined fluorescent in situ hybridization and a monoclonal antibody. Am. J. Trop. Med. Hyg. 68: 228-232.

Hoog, G. S., J. Guarro, J. Gené, and M. J. Figueiras. 2000. Atlas of clinical fungi, 2nd ed. Baarn/Delft: Centraalbureau voor Schinmelculture, Netherlands/Universitat Rovira i Virgilli, Spain.

Imamura, S., M. Kita, Y. Yamaoka, T. Yamamoto, A. Ishimaru, and H. Konishi. 2003. Vector potential of cockroaches for Helicobacter pylori infection. Am. J. Gastroenterol. 98: $1500-1503$.

Lemos, A. A., J. A. Lemos, M. A. Prado, F. C. Pimenta, E. Gir, H. M. Silva, and M.R.R. Silva. 2006. Cockroaches as carriers of fungi of medical importance. Mycoses 49: 23-25.

Lise, F., F.R.M. Garcia, and J. A. Lutinski. 2006. Association of ants (Hymenoptera: Formicidae) with bacteria in hospitals in the State of Santa Catarina. Rev. Soc. Bras. Med. Trop. 39: 523-526.

Mariconi, F.A.M. 1999. As baratas, pp. 13-33. In: F.A.M. Mariconi (ed.), Insetos invasores de residências. FEALQ, Piracicaba, São Paulo, Brazil.

Moreira, D.D.O., V. Morais, O. Vieira-da-Motta, A.E.C. Campos-Farinha, and A. Tonhasca, Jr. 2005. Ants as carriers of antibiotic-resistant bacteria in hospitals. Neotrop. Entomol. 34: 999-1006.

Moretti, M. L. 2007. A importância crescente das infecções fúngicas. Rev. Panam. Infectol. 9: 8-9.

Passera, L., and Aron, S. 2005. Les fourmis: comportement, organization sociale et evolution. Les Presses Scientifiques du CNRC, Ottawa, Canada.

Pedroso, R. S., K.R.C. Costa, J. C. Ferreira, and R. C. Candido. 2007. Avaliação da produção de melanina por espécies de Cryptococcus em quatro diferentes meios de cultura. Rev. Bras. Med. Trop. 40: 566-568.

Perdelli, F., M. L. Cristina, M. Sartini, A. M. Spagnolo, M. Dallera, G. Ottria, R. Lombardi, M. Grimaldi, and P. Orlando. 2006. Fungal contamination in hospital environments. Infect. Control Hosp. Epidemiol. 27: 44-47.

Pfaller, M. A., and W. L. Yu. 2001. Antifungal susceptibility testing. New technology and clinical applications. Infect. Dis. Clin. North Am. 15: 1227-1261.

Robinson, W. H. 1996. Urban entomology: insect and mite pests in the human environment. Chapman Hall, London, United Kingdom.

Rodovalho, C. M., A. L. Santos, M. T. Marcolino, A. M. Bonetti, and M.A.M. Brandeburgo. 2007. Urban ants and transportation of nosocomial bacteria. Neotrop. Entomol. 36: 454-458.

Ruiz-Esquide, F., M. C. Díaz, E. Wu, and V. Silva. 2002. Verrucous endocarditis secondary to Saccharomyces cerevisiae: a case report. Rev. Med. Chil. 130: 1165-1169.

Vidotto, V., S. Aoki, J. Pontón, G. Quindós, C. Y. Koga-Ito, and A. Pugliese. 2004. A new caffeic acid minimal synthetic medium for the rapid identification of Cryptococcus neoformans isolates. Rev. Iberoam. Micol. 24: 87-89.

Zarzuela, M.F.M., M.C.C.E. Ribeiro, and A.E.C. CamposFarinha. 2002. Distribuição de formigas urbanas em um hospital da região Sudeste do Brasil. Arq. Inst. Biol. 69: 85-87.

Received 3 June 2008; accepted 14 November 2008. 